\title{
NEW DATA ON TURKISH HYPOGEOUS FUNGI
}

\author{
OĞUzhan Kaygusuz ${ }^{1}$, ÖMer F. ÇOlaK ${ }^{2}$, \\ Neven Matočec ${ }^{3}$ \& Ivana Kušan ${ }^{3}$ \\ 'Pamukkale University, Faculty of Science and Arts, Department of Biology, \\ TR-20020 Kınıklı, Denizli, Turkey \\ ${ }^{2}$ Süleyman Demirel University, Vocational School of Health Services, \\ TR-32260 East Campus, Isparta, Turkey \\ ${ }^{3}$ Ruđer Bošković Institute, Bijenička cesta 54, HR-10000 Zagreb, Croatia
}

Kaygusuz, O., Çolak, Ö. F., Matočec, N. \& Kušan, I.: New data on Turkish hypogeous fungi. Nat. Croat. Vol. 27, No. 2, 257-269, 2018, Zagreb.

In this study, three species of hypogeous fungi are reported in different regions of Anatolian peninsula. Of these, Hydnocystis piligera is presented as the first record of this genus for Turkish mycobiota, while Melanogaster variegatus and Octaviania asterosperma are given as new locality records for Turkey. Macroscopic and microscopic photographs along with description of the newly recorded taxa are presented.

Key words: biodiversity, first record, taxonomy, Turkish truffles

Kaygusuz, O., Çolak, Ö. F., Matočec, N. \& Kušan, I.: Novi podaci o podzemnim gljivama Turske. Nat. Croat., Vol. 27, No. 2, 257-269, 2018, Zagreb.

Provedenim istraživanjem zabilježene su tri vrste podzemnih gljiva u različitim regijama poluotoka Anatolija. Nalaz vrste Hydnocystis piligera predstavlja prvi nalaz ovoga roda za mikobiotu Turske, dok su vrste Melanogaster variegatus i Octaviania asterosperma zabilježene na novim lokalitetima u Turskoj. $\mathrm{U}$ radu se prikazuju makroskopske i mikroskopske fotografije zajedno s tekstualnim podacima o zabilježenim vrstama.

Ključne riječi: bioraznolikost, prvi zapis, taksonomija, turske podzemne gljive

\section{INTRODUCTION}

Hypogeous fungi comprise species from the phyla Ascomycota (which include Tuber spp. i.e. true truffles), Basidiomycota (a part of false truffles) and some sporocarpic Glomeromycota (Colgan et al., 1999). Most hypogeous fungi are ectomycorrhizal fungi in symbiotic relationships with the roots of Pinaceae, Fagaceae, Betulaceae, Myrtaceae and Salicaceae (CAREY et al., 2002; Elliott et al., 2016; Nedelin et al., 2016). The fruiting bodies of these fungi develop partially or wholly underground, and have tuberate forms (GücIN et al., 2010; ŞEN et al., 2016).

*corresponding author's e-mail: of.colak@yahoo.com 
Because they develop underground, the spore distribution of hypogeous fungi, unlike that of epigeous fungi (above-ground), is not achieved through the air. The distribution of the spores of hypogeous fungi is frequently restricted in distance, and they have developed a spore distribution strategy that is dependent on animals (TRAPPE \& MASER, 1977). When the fruiting bodies or the spores of these fungi ripen, they begin to broadcast an aroma that is a chemical attractant to many animals (TRAPPE \& MASER, 1977; MLECzKO et al., 2010). These animals then dig the ripe fruitbodies out of the ground, break them up, and consume them partially or completely (TRAPPE \& MASER, 1977).

These fungi are both delicious and nutritious, and therefore they have been a sought-after part of the human diet since early times (Splivallo et al., 2011; Splivallo \& Culleré, 2016). Even though it is very difficult to grow some truffle species, they have been cultivated and traded for many years (ÇAKA \& TüRKOĞLU, 2016; ŞEN et al., 2016).

The Anatolian peninsula stands at the intersecting point of three phytogeographical regions (Euro-Siberian, Mediterranean and Irano-Turanian) in the Northern Hemisphere, and for this reason it has a rich plant biodiversity (DoĞAn \& AKATA, 2015; KAyGusuz \& ÇOLAK, 2017). This allows many species of ectomycorrhizal fungi (ÇoLAK et al., 2017) including hypogeous fungi to flourish (CAstellano \& TürKoĞLU, 2012; TürKoĞLU \& CASTELlANo, 2013, 2014; GEZER et al., 2014).

According to recent work (DoĞAN \& AKata, 2015; UzUN \& KaYA, 2017) and the Checklist of Turkish Truffles (ŞEN et al., 2016), 71 hypogeous fungi have been reported from Turkey, 26 of which are ascomycetous and 45 are basidiomycetous. The paper aims to make contributions to Turkish hypogeous fungi.

\section{MATERIAL AND METHODS}

The specimens were randomly collected from the provinces of Aydin, Bursa and Kütahya in Turkey, without the aid of trained dogs. According to Quezel \& BArbero (1985), Aydin province is characterised by a thermo-Mediterranean bioclimate in the broader littoral area represented by completely evergreen sclerophyllous dendro-vegetation with inclusions of thermophilic conifers (Pinus halepensis Mill., P. brutia Ten. and Cupressus sempervirens L.) and by meso-Mediterranean bioclimate represented mainly by evergreen-deciduous dendro-vegetation (composed of mixed elements and/or semi-evergreen species) situated in river valleys and surrounding mountains. On the other hand, Bursa and Kütahya provinces are part of a broad supra-Mediterranean belt, dominated by thermophilic deciduous trees (at least on calcareous soils) as well as of a montane-Mediterranean belt (etage montagnard-méditerraneen) represented by Pino-Cistion laurifolii, except for the highest mountains that are settled with Euro-Siberian altimontane Abies-Fagus tall forests. Fieldwork was designed to cover three mutually sharply different vegetational representatives of three bioclimatic zones. The research conducted in Aydin province was aimed at the thermo-Mediterranean littoral vegetation dominated by Pinus brutia and Cupressus sempervirens, while that performed in Kütahya province covered a montane-Mediterranean zone represented by Cedrus libani A. Rich., mixed with Cistus sp. and deciduous oaks. Research done in Bursa province was concentrated on a Euro-Siberian altimontane forest composed of Fagus orientalis Lipsky and Abies nordmanniana (Stev.) Spach. The specimens were photographed in the field, and the morphological and ecological characteristics were noted in the field notebook. The assessment of the mycorrhizal plant partners for Hydnocystis piligera without sampling of mycorrhizae has been made according to a previously elaborated protocol (MAтоčEc, 


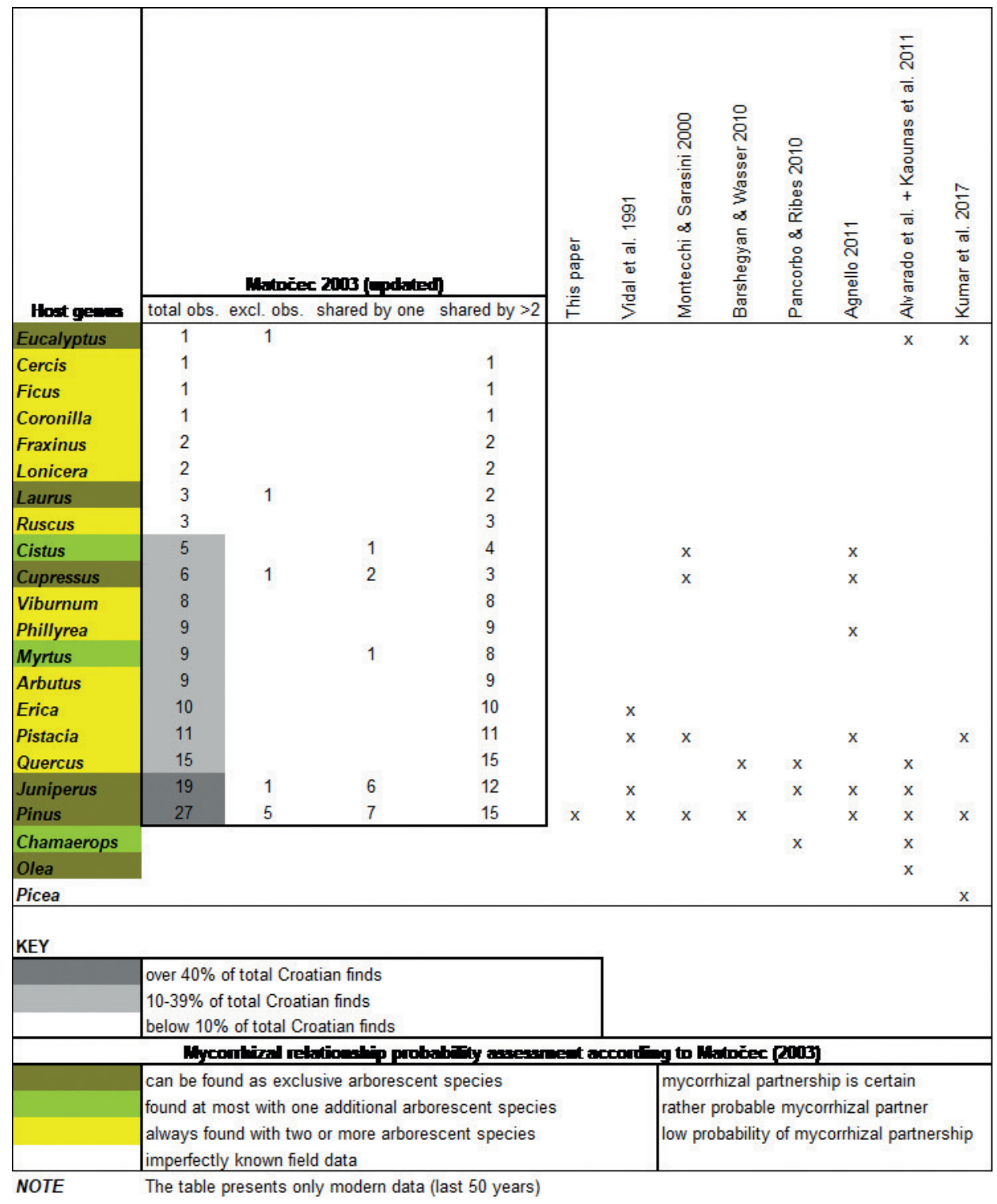

Tab. 1. Host genus affinity and mycorrhizal relationship probability for Hydnocystis piligera according to direct field observations.

2003). Soil characteristics and information about the bedrock are read off from various pedological and geological thematic maps and data. The measurements of microscopic features were taken on dry materials mounted in $\mathrm{KOH}$, Congo red and Melzer's reagent. Identification of the samples was conducted according to the references given in Table 2, 3 and 4. Molecular methods in species identification are not used since all species treated are easily recognizable by morphological characters, organoleptic features and 
ecology. Dried samples are kept in the personal fungarium of the second author at Süleyman Demirel University, Isparta. The names of taxa and authors are quoted according to MycoBank (www.mycobank.org) and Index Fungorum (www.indexfungorum.org).

Tab. 2. Comparison of micro- and macroscopic characters of $H$. piligera.

\begin{tabular}{|c|c|c|c|c|}
\hline $\begin{array}{c}\text { Size of } \\
\text { ascoma }(\mathrm{mm})\end{array}$ & Size of asci $(\mu \mathrm{m})$ & $\begin{array}{c}\text { Size of ascospores } \\
(\mu \mathrm{m})\end{array}$ & $\begin{array}{l}\text { Width of } \\
\text { paraphyses at } \\
\text { the top }(\mu \mathrm{m})\end{array}$ & References \\
\hline $4-20$ & $375-450 \times 25-38$ & $24-35$ & $1-3$ & BuRDSAL (1968) \\
\hline 10 & $25-35$ & $25.5-33.5$ & - & VIDAL et al. (1991) \\
\hline $10-25$ & $180-350 \times 20-45$ & $22-31$ & $1-3$ & BARSEGHYAN \& WASSER (2010) \\
\hline $5-20$ & - & $25-32.7 \times 24.7-32$ & - & Pancorbo \& Ribes (2010) \\
\hline $5-35$ & $190-310 \times 30-45$ & $28-36$ & $3-5$ & Agnello (2011) \\
\hline $5-35$ & $300 \times 50$ & $27-32$ & 5 & KaOUnAs et al. (2011) \\
\hline $5-40$ & $250-300 \times 30-50$ & $28-35$ & $3-5$ & Kumar et al. (2017) \\
\hline $5-25$ & $200-300 \times 25-45$ & $25.4-37.3(-37.7)$ & $3-5$ & This study \\
\hline
\end{tabular}

Tab. 3. Comparison of micro- and macroscopic characters of M. variegatus.

\begin{tabular}{|c|c|c|c|}
\hline $\begin{array}{l}\text { Size of basidioma } \\
(\mathrm{mm})\end{array}$ & Size of basidia $(\mu \mathrm{m})$ & Size of basidiospores $(\mu \mathrm{m})$ & References \\
\hline- & - & $10-5$ & MAsSEe (1889) \\
\hline - & - & $7.5-10 \times 5.0-7.5$ & ZeLLER \& Dodge (1936) \\
\hline $20-25 \times 10-15$ & - & $(6.5-)$ 8-10.5 × 5-6.5 (-11) & CÁZARES et al. (1992) \\
\hline $20-40$ & - & $(6-) 7.5(-8.5) \times 4(-5.5)$ & Honrubia et al. (1992) \\
\hline $10-60$ & $40-50 \times 8-10$ & $7-10 \times 5-7$ & Moreno-ARroyo et al. (2005) \\
\hline $20-50$ & $15-20 \times 5-8$ & $5-10 \times 3.5-4.5$ & Sesli \& Moreau (2015) \\
\hline $35-50$ & - & (5-) 5.5-8.5 (-9.5) × 4-5 & This study \\
\hline
\end{tabular}

Tab. 4. Comparison of micro- and macroscopic characters of O. asterosperma.

\begin{tabular}{|c|c|c|c|}
\hline $\begin{array}{c}\text { Size of basidioma } \\
(\mathrm{mm})\end{array}$ & Size of basidia $(\mu \mathrm{m})$ & Size of basidiospores $(\mu \mathrm{m})$ & References \\
\hline- & - & $14-15$ & Massee (1889) \\
\hline $35-50$ & $20-22$ & $13-16$ & Zeller \& Dodge (1936) \\
\hline- & - & $9-11$ & Sмітн (1962) \\
\hline $10-30$ & - & $13-18$ & ARORA (1986) \\
\hline $20-30$ & - & $16-18$ & Yoshimi \& Doi (1989) \\
\hline $10-50$ & - & $10-20$ & ELLIS \& ElLis (1990) \\
\hline 10 & $20.5-23 \times 9.5-13$ & $14-16.5$ & CÁZAREs et al. (1992) \\
\hline 30 & $20-35 \times 7-15$ & $9-11 \times 12-17$ & MARTín et al. (1994) \\
\hline $10-20$ & - & $9-12$ & VIDAL (1994) \\
\hline $16-25$ & $30 \times 8-12$ & $10-12$ & LENNE (2005) \\
\hline $10-25$ & $25-35 \times 5-10$ & $10-13 \times 10-12$ & Moreno-Arroyo et al. (2005) \\
\hline $10-15 \times 18-25$ & - & $13.8-17.5(-18.8)$ & Huffman et al. (2008) \\
\hline $7.5-25$ & - & $18-19$ & HobARt (2009) \\
\hline $25-35$ & $21-28 \times 10-15$ & $13-18$ & MLeCzKo et al. (2010) \\
\hline $6-15$ & $5-10 \times 20-40$ & $(8.8-)$ 10.5-11.4 × 10.5-11.4 (-12.3) & TüRкоĞLu et al. (2015) \\
\hline $10-20$ & - & $(11.5-) 12-13.5(-14) \times(9-) 10-12(-12.5)$ & This study \\
\hline
\end{tabular}




\section{RESULTS AND DISCUSSION}

\section{A record of a new hypogeous fungus for Turkey}

Ascomycota Caval.-Sm.

Pezizales J. Schröt.

Pyronemataceae Corda

Hydnocystis piligera Tul. \& C. Tul., Giornale Botanico Italiano 1 (2): 59 (1844) Fig. 1.

Ascoma 5-25 mm in diameter, closed astipitate ptychothecium, hypogeous when small, larger ascomata semi-hypogeous or sometimes epigeous, generally globose to subglobose, sometimes slightly lobed, hollow, pale yellow, yellowish ochraceous to flesh-coloured, finely hairy, pubescent. Peridium composed of an outer layer of wavy or creased hairs forming an up to $0.5 \mathrm{~mm}$ thick layer, and an inner layer composed of round or polygonal elements. Gleba thin, whitish, swollen cotton-like structure covered in fine hairs, and with a clear aroma of sweet ripe fruit. Asci 200-300 × 25-45 $\mu \mathrm{m}$, cylindrical, tapering gradually from apex toward base, inamyloid, uniseriate, 8 -spored. Ascospores 25.4-37.3(-37.7) $\mu \mathrm{m}$ in diam., $\mathrm{Q}=1.0$ (1.1), $\mathrm{Me}=31.3 \times 30.5, \mathrm{Qe}=1.0$, globose, hyaline, smooth, comparatively thin-walled, without oil drops. Paraphyses 3-5 $\mu \mathrm{m}$ broad at the apex, filiform, septate, generally longer than asci, hyaline, thin-walled.

Habitat: Fruitbodies of $H$. piligera grow hypogeally or semi-hypogeally, in sandy soils developed from calcareous rocks containing various levels of $\mathrm{CaCO}_{3}$, especially in coastal thermophilic pine forests and scrubland in Mediterranean ecosystems (thermo-Mediterranean fully evergreen sclerophyllous vegetation type), most frequently associated or most certainly mycorrhizal with plant genera such as Pinus, Juniperus, Quercus, Pistacia, Olea, Cupressus, Cistus, Laurus and Eucalyptus (Tab. 1).

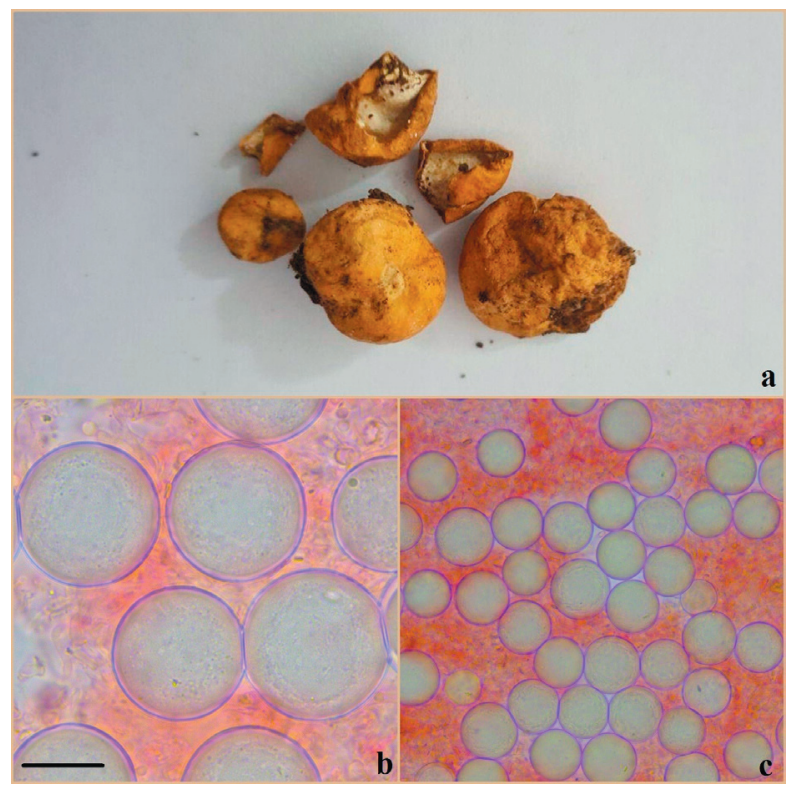

Fig. 1. Hydnocystis piligera; a: ascomata, b-c: ascospores (in Congo red) (scale bar: $20 \mu \mathrm{m}$ ). 
Specimen examined: Turkey. Aydın Province, Kuşadası district, on the ground, under Pinus brutia, 12 m a.s.l., 21 Nov 2015, leg. \& det. O. Kaygusuz (OKA 1504).

Discussion: In previous studies, Hydnocystis piligera and H. clausa (Tul. \& C. Tul. Ceruti) have been reported from different parts of Europe (PANCORBo \& Ribes, 2010). These two species, which share similar habitats, can be easily distinguished by their macromorphological and microscopic characteristics. The two species were however ascribed to different genera, namely Hydnocystis and Geopora in some studies (BuRDSall, 1968; Matočec, 2003; Alvarado et al., 2011; Kaounas et al., 2011; Kumar et al., 2017). H. piligera has an ascoma that varies from pale yellow to skin colour and globose spores 25.4-37.7 $\mu \mathrm{m}$ in size, and is easily distinguishable from $H$. clausa, now a certain member of Geopora, which has a dark coloured ascoma and ellipsoidal (20-30 $\times$ 13-18) spores (Moreno-Arroyo et al., 2005; Pancorbo \& Ribes, 2010; Agnello, 2011).

Detailed descriptions of $H$. piligera have been provided in previous studies (BURDSAll, 1968; Montecchi \& SARAsini, 2000; MatočEc, 2003; Barseghyan \& Wasser, 2010; Pancorbo \& Ribes, 2010; Agnello, 2011; Kaounas et al., 2011; Kumar et al., 2017). A comparative analysis of Turkish specimens and data provided by other authors is presented in Tab. 2: it shows that the sizes of macroscopic and microscopic structures of our samples are compatible with previous findings.

H. piligera has been reported hitherto from Algeria, Austria, Belgium, China, Croatia, Cyprus, France, Germany, Greece, Israel, Italy, Lichtenstein, Netherlands, Russia, Spain and Switzerland (Burdsall, 1968; Vidal et al., 1991; Matočec, 2003; Montecchi \& Sarasini, 2000; Barseghyan \& Wasser, 2010; Pancorbo \& Ribes, 2010; Agnello, 2011; Alvarado et al., 2011; Kaounas et al., 2011; Kumar et al., 2017). Although this primarily Mediterranean species has been reported from the medio-European area too, it is regarded as very rare (Switzerland) to extremely rare (Germany) (cf. www.123pilze. de, also Krieglsteiner (1993)), while the species is missing from recent species list of Austria (D̈̈mon \& Krisai-Greilhuber, 2017). H. piligera is reported in this study as a newly reported genus for Turkey, extending the known distribution to a new geographical region (Sesli \& Denchev, 2008; Solak et al., 2015; Şen et al., 2016).

In terms of habitat (Tab. 1), it has been reported in previous studies that H. piligera generally grows under Angiosperms (Chamaerops humilis L., Cistus spp., Erica multiflora L., Eucalyptus sp., Olea europaea L., Phillyrea angustifolia L., Pistacia lentiscus L., P. terebinthus L., Quercus ilex L.), but even more frequently under Gymnosperms (especially Pinus spp., Juniperus spp. and Cupressus sempervirens) (Vidal et al., 1991; MontecChi \& Sarasini, 2000; Matočec, 2003; Barseghyan \& Wasser, 2010; Pancorbo \& Ribes, 2010; Agnello, 2011; Kaounas et al., 2011; Kumar et al., 2017). The samples identified in the present study were collected very close to the coast under Pinus brutia.

\section{New localities of two hypogeous fungi for Turkey}

\section{Basidiomycota Whittaker ex Moore}

Boletales E.-J. Gilbert

Melanogastraceae E. Fisch.

Melanogaster variegatus (Vittad.) Tul. \& C. Tul., Fungi Hypogaei: Histoire et Monographie des Champignons Hypogés: 92, t. 2:4, 12:6 (1851) Fig. 2. 


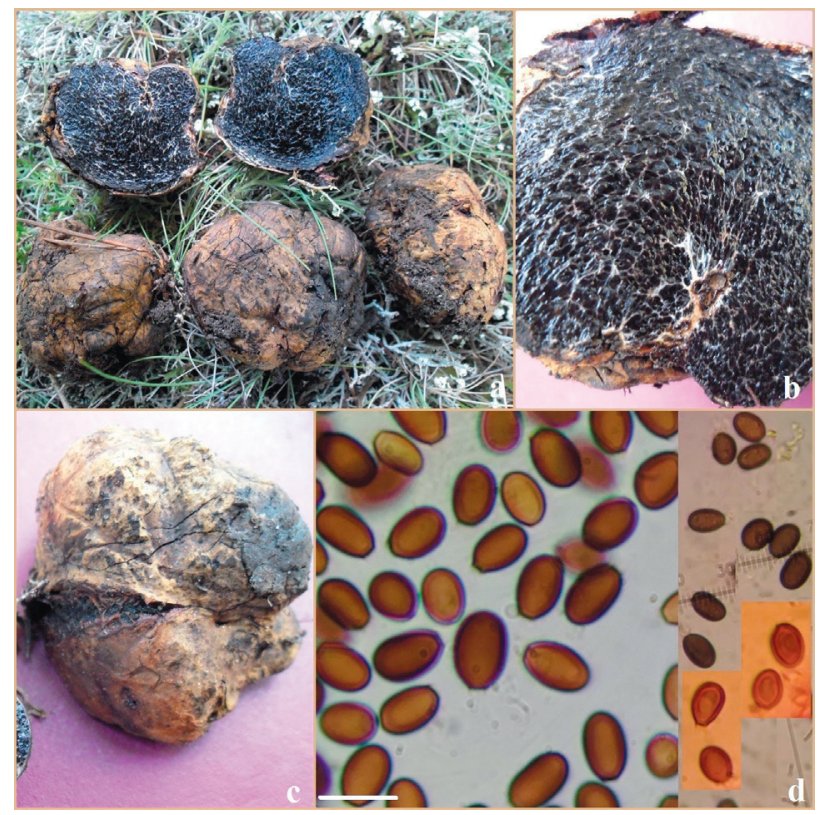

Fig. 2. Melanogaster variegatus; a-c: basidiomata, d: basidiospores (in $\mathrm{KOH}$ and Congo red) (scale bar: $10 \mu \mathrm{m}$ ).

Habitat: Fruitbodies of M. variegatus grow hypogeally or semi-hypogeally, under Cedrus libani, near Quercus sp. and Cistus sp. mixed montane-Mediterranean forest.

Specimen examined: Turkey. Kütahya Province, Domaniç district, Küçükköy village, 19 May 2014, leg. \& det. Ö.F. Çolak (ÖFÇ 893).

Discussion: Melanogaster variegatus can sometimes be confused with M. broomeanus Berk. However, M. variegatus has elliptical to ovoid spores, while $M$. broomeanus has ellipsoid-cylindrical spores (BREITENBACH \& KRÄNZlin, 1986; Honrubia et al., 1992; LACHEVA, 2015; TüRKOĞLU, 2015). Also, the peridium of M. variegatus is yellowish-brown in colour, while that of M. broomeanus is pinkish (CÁzAres et al., 1992; Honrubia et al., 1992). Because of its smaller spore dimensions, M. variegatus (5-9.5 $\times 4-5 \mu \mathrm{m})$ can also be easily distinguished from M. ambiguus (Vittad.) Tul. \& C. Tul. (13-17 × 6-10 $\mu \mathrm{m})$ and M. macrosporus Velen. (10-14×5-6 $\mu \mathrm{m})$ (Uzun et al., 2014; Elliot et al., 2016). These two latter species are also easily separated from both $M$. broomeanus and $M$. variegatus by their specific and well differentiated aroma.

M. variegatus was first reported from Turkey by SESLI \& Moreau (2015). The macroscopic and microscopic characteristics of M. variegatus in the present study, which presents a second locality record for the mycobiota of Turkey, are in accordance with information in the literature (Tab. 3).

M. variegatus has been reported so far from Algeria, France, Germany, Greece, Hungary, Italy, Mexico, Spain, Turkey, USA (Massee, 1889; Zeller \& Dodge, 1936; Cázares et al., 1992; Honrubia et al., 1992; Moreno-Arroyo et al., 2005; Diamandis \& Perlerou, 2008; Nuhn et al., 2013; Bratek et al., 2013; Pecoraro et al., 2014; Sesli \& Moreau, 2015). In this study, a second locality record for Turkey is presented for M. variegatus. 
In previous studies, M. variegatus has been reported as growing with Fagus sp., Quercus sp., Pinus sp., Alnus glutinosa (L.) Gaertn., A. incana (L.) Moench, Anthyllis cytisoides L., Cistus clusii Dunal, C. incanus L., C. monspeliensis L., Helianthemum almeriense Pau, Quercus canbyi Trel., Q. ilex L. and Q. suber L. (Massee, 1889; Zeller \& DodGe, 1936; Cázares et al., 1992; Honrubia et al., 1992; Diamandis \& Perlerou, 2008; Ortega et al., 2010; Graf \& Frei, 2013; Sesli \& Moreau, 2015). In the present study, a new habitat for M. variegatus, Cedrus libani, is reported as an update to the literature.

\section{Basidiomycota}

\section{Boletales}

Boletaceae Chevall.

Octaviania asterosperma Vittad., Monographia Tuberacearum: 17, t. 3:7 (1831), Syn.: Arcangeliella asterosperma (Vittad.) Zeller \& C.W. Dodge, Annals of the Missouri Botanical Garden 22: 366 (1935) Fig. 3.

Habitat: Fruitbodies of O. asterosperma grow hypogeally or semi-hypogeally, under Fagus orientalis and Abies nordmanniana (Stev.) Spach subsp. bornmuelleriana (Mattf.) Coode et Cullen mixed Euro-Siberian altimontane forest.

Specimen examined: Turkey. Bursa Province, Uludağ National Park, 7 Sep 2017, leg. \& det. Ö.F. Çolak (ÖFÇ 1302).

Discussion: Octaviania Vittad. (orthographic variant: Octavianina O. Kuntze (GAMs, 1999); Boletales), is a genus of truffle-like fungi from the Boletaceae family. This genus has a wide distribution, and so far has 15-20 accepted species (KIRK et al., 2008; OrIHARA et al., 2012). Various species of the Octaviania Vittad., Sclerogaster R. Hesse and Wa-

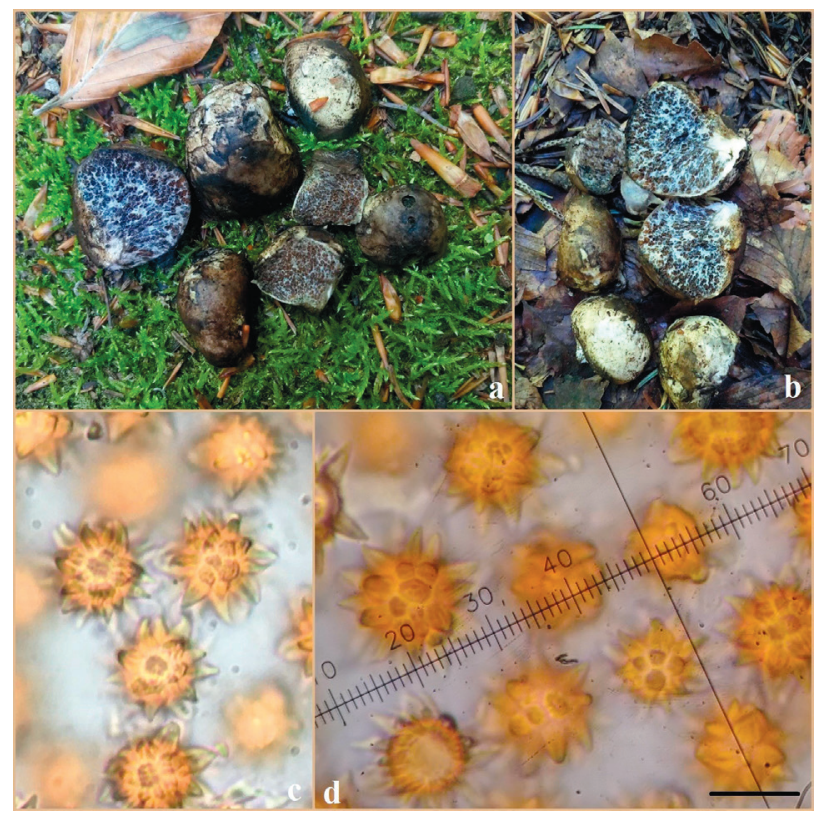

Fig. 3. Octaviania asterosperma; a-b: basidiomata, c: basidiospores (in Melzer's reagent), d: basidiospores (in $\mathrm{KOH})$ (scale bar: $10 \mu \mathrm{m})$. 
kefieldia Corner \& Hawker (genera of the order Boletales) can be confused under certain ecological conditions. However, both Octaviania and Wakefieldia species have spore diameters of generally more than $10 \mu \mathrm{m}$, while those of the genus Sclerogaster have spores smaller than $10 \mu \mathrm{m}$. In addition, while the spores of Octaviania species are subglobose and have spore ornamentation extending for approximately $4 \mu \mathrm{m}$ and are dextrinoid in character, those of the genus Wakefieldia have spore ornamentation which extends approximately $1.5 \mu \mathrm{m}$, and are not dextrinoid in character (LENNE, 2005).

O. asterosperma can be sometimes confused with O. olida Malençon \& Astier. While O. asterosperma has a peridium varying in colour from yellowish to brownish and round spores, O. olida has a yellow peridium and ellipsoid spores with straight spines (Astier, 1993; MLeсzко et al., 2010). Also, Mleczкo et al. (2010) reported that yellow woolly colonies of Sepedonium laevigatum Sahr \& Ammer formed on the surface of the basidiomata of ripe O. asterosperma. However, S. laevigatum is a non-specialised parasite/saprotroph on a number of boletalean species and could not be used as an indicator of host species. The morphological and microscopic characteristics of $O$. asterosperma given in the present study are in accordance with the data reported by previous researchers (Tab. 4).

O. asterosperma has been reported from Asia (Japan) (Yoshimi \& Doi, 1989), Algeria, Europe (Austria, Belgium, Bulgaria, Czech Republic, Czechoslovakia, Denmark, England, France, Germany, Hungary, Ireland, Italy, Norway, Poland, Portugal, Serbia, Spain, Sweden, Switzerland, Turkey, Netherlands, Ukraine) (Massee, 1889; Pim, 1898; Zeller \& Dodge, 1936; Smith, 1962; Martín et al., 1994; Vidal, 1994; Lenne, 2005; Hobart, 2009; MleczKo et al., 2010; Orihara et al., 2012; BrateK et al., 2013; Nuhn et al., 2013; Rana et al., 2015; TürkoĞLu et al., 2015), North America (Mexico, USA) (Zeller \& Dodge, 1936; Arora, 1986; CÁzares et al., 1992) and North Africa (Massee, 1889). O. asterosperma has a broad distribution, mostly in Europe but also in the rest of the world, and in this study a new locality record is reported from Turkey.

In terms of habitat, O. asterosperma has been reported in many previous studies as growing together with Alnus glutinosa (L.) Gaertn., Castanea sativa Mill., Carpinus sp., Corylus sp., Fagus orientalis, F. sylvatica L., Picea orientalis (L.) Link., Pinus sylvestris L., Pseudotsuga sp. (Douglas fir), Quercus sp., Q. ilex subsp. ballota [Desf.] Samp., Q. rysophylla Weath., Q. suber L., Rhododendron ponticum L., Tilia sp., Salix caprea L. and Sequoia sp. (Redwood) (Arora, 1986; Cázares et al., 1992; Vidal, 1994; Desjardin, 2003; Lenne, 2005; Moreno-Arroyo et al., 2005; Mleczko et al., 2010; TürkoĞLu et al., 2015). The sample presented in this study is similar in terms of general habitat data to those reported in the literature.

\section{CONCLUSIONS}

According to the literature 27 genera of the family Pyronemataceae have been reported from Turkey (Sesli \& Denchev, 2008; SolaK et al., 2015; ÇolaK \& Kaygusuz, 2017a, 2017b; Uzun et al., 2018). In this study, Hydnocystis piligera is reported as a new record for the mycobiota of Turkey, becoming the $28^{\text {th }}$ known genus of the Pyronemataceae occurring in this country. The ecological data are compared to those collected from Croatia (MATOčEC, 2003) where this species has been specially monitored for 30 years with almost two thirds of all finds being recorded under one or several Pinus species, which is in high accordance with the Turkish record (Tab. 1). With the extension of its known range to Turkey, the main ecological frame of $H$. piligera in Europe, Asian Middle East and Africa falls into the thermo-Mediterranean zone (represented by fully evergreen sclerophyllous and/or 
thermophilic coniferous vegetation) of the Mediterranean basin where this species is fairly common. The number of hypogeous fungi in Turkey has increased from 71 to 72 (DoĞAN \& AkATA, 2015; ŞEN et al., 2016; Uzun \& KAYA, 2017). Also, new locality records have been reported from Turkey for two truffles: Melanogaster variegatus and Octaviania asterosperma both having wide transcontinental ranges.

Received July 23, 2018

\section{REFERENCES}

Agnello, C., 2011: Ritrovamenti nel Salento di Hydnocystis piligera Tul. e Hydnocystis clausa (Tul. \& C. Tul.) Ceruti. Ascomycete.org, 2(4), 9-17.

Alvarado, P., Moreno, G., Manjón, J.L., Gelpi, C., Kaounas, V., Konstantinidis, G., Barseghyan, G.S. \& Venturella, G., 2011: First molecular data on Delastria rosea, Fischerula macrospora and Hydnocystis piligera. Boletín de la Sociedad Micológica de Madrid, 35, 75-81.

Arora, D., 1986: Mushrooms demystified. Ten Speed Press, Berkeley.

Astier, J., 1993: Un Octavianina nouveau Octavianina olida Malençon et Astier, sp. nov. Documents Mycologiques, 22(88), 17-20.

BARSEghYAN, G. S. \& WASSER, S. P., 2010: Species diversity of hypogeous Ascomycetes in Israel. Mycobiology, 38(3), 159-165.

BrateK, Z., MerÉNyI, Z. \& VARGA, T., 2013: Changes of hypogeous fungi in the Carpathian-Pannonian region in the past centuries. Acta Mycologica, 48(1), 33-39.

Breitenbach, J., \& KRÄnzlin, F., 1986: Fungi of Switzerland, Vol. 2. Verlag Mykologia, Luzern.

Burdsall, H.H., 1968: A revision of the genus Hydnocystis (Tuberales) and of the hypogeous species of Geopora (Pezizales). Mycologia, 60(3), 496-525.

Carey, A.B., Colgan, W.C. III, W., Trappe, J.M. \& Molina, R., 2002: Effects of forest management on truffle abundance and squirrel diets. Northwest Sci., 76, 148-157.

Castellano, M.A., \& TürkoĞLu, A., 2012: New records of truffle taxa in Tuber and Terfezia from Turkey. Turkish Journal of Botany, 36(3), 295-298.

Cázares, E., García, J., Castillo, J. \& Trappe, J.M., 1992: Hypogeous fungi from northern Mexico. Mycologia, 84(3), 341-359.

Colgan, W.C. III, Carey, A.B., Trappe, J.M., Molina, R. \& Thysell, D., 1999: Diversity and productivity of hypogeous fungal sporocarps in a variably thinned Douglas-fir forest. Canadian Journal of Forestry Resources, 29, 1259-1268.

ÇAкA, Ş. \& TürкоĞLu, A., 2016: Some Commercial Truffles and Their Natural Habitats. Mugla Journal of Science and Technology, Special Issue, 13-14.

ÇolaK, Ö.F. \& KayGusuz, O., 2017a: Octospora leucoloma (Pyronemataceae): a new bryoparasitic genus record for Turkish mycobiota. Phytologia Balcanica, 23(3), 345-348.

ÇoLAK, Ö.F. \& KAYGusuz, O., 2017b: A new psilopezioid fungi record on relict endemic Liquidambar orientalis in Turkey. Forestry Ideas, 23(2), 160-165.

ÇolaK, Ö.F., KaYGUsuz, O. \& IşıLoĞLU, M., 2017: Two Lactarius species mycorrhizal with Cistus laurifolius in Turkey. Current Research in Environmental \& Applied Mycology, 7(1), $26-32$.

Dämon, W. \& KRIsaI-Greilhuber, I., 2017: Die Pilze Österreichs. Verzeichnis und Rote Liste 2016. Teil: Makromyzeten. Österr. Mykolog. Ges., Wien. p. 609.

Desjardin, D.E., 2003: A unique ballistosporic hypogeous sequestrate Lactarius from California. Mycologia, 95(1), 148-155.

Diamandis, S. \& Perlerou, C., 2008: Recent records of hypogeous fungi in Greece. Acta Mycologica, 43(2): 139-142.

DoĞan, H.H. \& AкATA, I., 2015: New Additions to Turkish Gasteroid Fungi. Kastamonu University Journal of Forestry Faculty, 15(2), 329-333.

Elliott, T.F., TürkoĞLu, A., Trappe, J.M. \& Yaratanakul Güngör, M., 2016: Turkish truffles 2: eight new records from Anatolia. Mycotaxon, 131(2), 439-453.

ELLIS, M.B. \& ElLis, J.P., 1990: Fungi without gills (Hymenomycetes and Gasteromycetes): An identification handbook. Chapman \& Hall, UK. 
Gams, W., 1999: Proposals to conserve or reject. Report of the Committee for Fungi: 8. Taxon, 48, 807-810.

Gezer, K., Kaygusuz, O., Çelı́, A. \& IşıloĞLu, M., 2014: Ecological characteristics of truffles growing in Denizli Province, Turkey. (Journal of Food, Agriculture \& Environment) J Food Agric Environ, 12(2), 1105-1109.

GrAF, F. \& FrEI, M., 2013: Soil aggregate stability related to soil density, root length, and mycorrhiza using site-specific Alnus incana and Melanogaster variegatus sl. Ecological engineering, 57, 314-323.

Gücin, F., Kaya, A., Soylu, M.K. \& Uzun, Y., 2010: Picoa Vittad., a new truffle genus record for Turkey. Biological Diversity and Conservation, 3(3), 23-25.

Новакт, C., 2009: Three rarely recorded truffle species: or news from the underground!. Field Mycology, 10(1), 5-8.

Honrubia, M., Cano, A. \& Molina-Ninirola, C., 1992: Hypogeous fungi from southern Spanish semi-arid lands. Persoonia-Molecular Phylogeny and Evolution of Fungi, 14(4), 647-653.

Huffman, D.M., Tiffany, H.L., Knaphus, G. \& Healy, R.A., 2008: Mushrooms and other fungi of the midcontinental United States, Second Edition. University of Iowa Press.

Kaounas, V., Assyov, B. \& Alvarado, P., 2011: New data on hypogeous fungi from Greece with special reference to Wakefieldia macrospora (Hymenogastraceae, Agaricales) and Geopora clausa (Pyronemataceae, Pezizales). Mycologia Balcanica, 8, 105-113.

Kaygusuz, O. \& ÇolaK, Ö.F., 2017: Typhula spathulata - first record from Turkey. Czech Mycology, 69(2), 125-131.

Kirk, P.M., Cannon, P.F., Minter, D.W. \& Stalpers, J.A., 2008: Dictionary of the Fungi (10th ed.). Wallingford, UK: CAB International. p. 478.

Krieglsteiner, G.J., 1993: Verbreitungsatlas der Großpilze Deutschlands (West). Band 2, Schlauchpilze. Verlag Eugen Ulmer, Stuttgart. p. 596.

Kumar, L.M., Smith, M.E., Nouhra, E.R., Orihara, T., Sandoval Leiva, P., Pfister, D.H., Mclaughlin D.J., Trappe, J.M. \& Healy, R. A., 2017: A molecular and morphological re-examination of the generic limits of truffles in the tarzetta-geopyxis lineage - Densocarpa, Hydnocystis, and Paurocotylis. Fungal Biology, 121(3), 264-284.

Lacheva, M., 2015: New records of Melanogaster species (Fungi, Boletales) in Bulgaria. Journal of Biodiversity and Environmental Sciences, 6(1), 492-498.

Lenne, M., 2005: Octaviania asterosperma, un champignon hypogé retrouvé au Bois de la Cambre. Revue du Cercle Mycolgie de Bruxelles, 5, 55-64.

Martín, M.P., Tabarés, M. \& Rocabruna, A., 1994: Octavianina asterosperma (Vitt.) O. Kuntze 1898. Societat Catalana de Micologia, 227, 265-266.

Matočec, N., 2003: Studies in Mediterranean Ascomycota (I). Ecology and distribution of the genus Hydnocystis in Croatia, with taxonomic remarks. The Third International Balkan Botanical Congress. Sarajevo, Bosnia-Herzegovina, 164. - poster presentation.

Massee, G., 1889: A monograph of the British Gastromycetes. Annals of Botany, 4(13), 1-103.

MleczKo, P., Kozak, M., Ławrynowicz, M. \& Dubiel, G., 2010: Octaviania asterosperma (hypogeous Basidiomycota) Recent data to ecology and distribution. Acta Mycologica, 45(2), 133-144.

Montecchi, A. \& Sarasini, M., 2000: Fungi Ipogei d'Europa. A.M.B. Fondazione, Centro Studi Micologici, Vicenza. p. 714.

Moreno-Arroyo, B., Gómez, J. \& Pulido, E., 2005: Tesoros de nuestro montes. Trufas de Andalucía. Consejería de Media Ambiente, Junta de Andalucía. Córdoba.

Nedelin, T., Gyosheva, M., Kostov, K. \& Savev, S., 2016: New records and data on hypogeous ectomycorrhizal fungi in Bulgaria. Forestry Ideas, 22(2), 113-126.

Nuhn, M.E., Binder, M., Taylor, A.F.S., Halling, R.E. \& Hibbett, D.S., 2013: Phylogenetic overview of the Boletineae. Fungal Biology, 117(7-8), 479-511.

Orihara, T., Smith, M.E., Shimomura, N., Iwase, K. \& Maekawa, N., 2012: Diversity and systematics of the sequestrate genus Octaviania in Japan: two new subgenera and eleven new species. Persoonia: Molecular Phylogeny and Evolution of Fungi, 28, 85-112.

Ortega, A., Lorite, J. \& VAlle, F., 2010: Mycorrhizal macrofungi diversity (Agaricomycetes) from Mediterranean Quercus forests; a compilation for the Iberian Peninsula (Spain and Portugal). Nova Hedwigia, 91(1-2), 1-31.

Pancorbo, F. \& Ribes, M. A., 2010: Setas de dunas mediterráneas. Bol. Soc. Micol. Madrid, 34, $271-294$.

Pecoraro, L., Angelini, P., Arcangeli, A., Bistocchi, G., Gargano, M. L., La Rosa, A., Lunghini, D., Polemis, E., Rubini, A., Saitta, A., Venanzoni, R. \& Zervakis, G.I., 2014: Macrofungi in Mediterrane- 
an maquis along seashore and altitudinal transects. Plant Biosystems-An International Journal Dealing with all Aspects of Plant Biology, 148(2), 367-376.

PIM, G., 1898: The fungi of the counties of Dublin and Wicklow. The Irish Naturalist, 7(8), 173-185.

Quezel, P. \& Barbero M., 1985: Carte de la végétation potentielle de la région Méditerranéenne. Feuille $\mathrm{N}^{\circ} 1$ : Méditerranée orientale. Éditions du centre de la recherche scientifique. Paris.

Rana, G.L., Mang, S.M. \& CAMEle, I., 2015: Biodiversity of Hypogeous Fungi in Basilicata (pp. 305-318). In, Vastola, A. (Ed.) The Sustainability of Agro-Food and Natural Resource Systems in the Mediterranean Basin, Springer.

Sesli, E. \& Denchev, C.M., 2008: Checklists of the Myxomycetes, larger Ascomycetes, and larger Basidiomycetes in Turkey. - Mycotaxon, 106, 65-67. + [complete version, 1-145, new version uploaded in January 2014].

Sesli, E. \& Moreau, P. A., 2015: Taxonomic studies on some new fungal records from Trabzon, Turkey. Turkish Journal of Botany, 39(5), 857-866.

Sмiтh, A.H., 1962: Notes on astrogastraceous fungi. Mycologia, 54(6), 626-639.

SolaK, M.H., IşıloĞLu, M., Kalmiş, E. \& Allı, H., 2015: Macrofungi of Turkey, Checklist, vol. 2. Üniversiteliler Ofset, İzmir.

Splivallo, R. \& Culleré, L., 2016: The smell of truffles: from aroma biosynthesis to product quality. Soil Biol, 47, 393-407.

Splivallo, R., Ottonello, S., Mello, A. \& Karlovsky, P., 2011: Truffle volatiles: from chemical ecology to aroma biosynthesis. New Phytologist, 189, 688-699.

Şen, İ., Alli, H. \& Civelek, H.S., 2016: Checklist of Turkish Truffles. Turkish Journal Life Sciences, 1(2), 103-109.

Trappe, J.M. \& Maser, C., 1977: Ectomycorrhizal fungi: Interactions of mushrooms and truffles with beasts and trees. In WALters, T. (Ed.): Mushrooms and Man, an Interdisciplinary Approach to Mycology. Linn-Benton Community College, Albany, Oregon.

TürkoĞLu, A., 2015: Yeraltındaki Gizli Hazine: Trüf Mantarları. T.C. Orman ve Su İşleri Bakanlığı Orman Genel Müdürlüğü, Ankara.

TürkoĞlu, A. \& Castellano, M.A., 2013: New records of truffle fungi (Basidiomycetes) from Turkey. Turkish Journal of Botany, 37(5), 970-976.

TürkoĞlu, A. \& Castellano, M.A., 2014: New records of some Ascomycete truffle fungi from Turkey. Turkish Journal of Botany, 38(2), 406-416.

TürkoĞLu, A., Castellano, M.A., Trappe, J.M. \& Güngör, M.Y., 2015: Turkish truffles I: 18 new records for Turkey. Turkish Journal of Botany, 39(2), 359-376.

Uzun, Y. \& Kaya, A., 2017: A Hypogeous Lactarius sp., New to Turkish Mycobiota. The Journal of Fungus, 8(2), 163-167.

Uzun, Y., Acar, İ. \& Akata, I., 2014: Notes on Turkish Melanogaster. Ot Sistematik Botanik Dergisi, 21(2), 113-118.

Uzun, Y., Karacan, İ.H., YAKar, S. \& Kaya, A., 2018: New bryophillic Pyronemataceae records for Turkish Pezizales from Gaziantep province. Anatolian Journal of Botany, 2(1), 28-38.

VIDAL, J.M., 1994: Algunos hongos hipogeos interesantes para la micoflora Catalana. Butll. Soc . Catalana Micol., 16-17, 221-248.

Vidal, J.M., Rocabruna, A. \& Tabarés, M., 1991: Algunos hongos hipogeos (Ascomycotina y Basidiomycotina) interesantes para la micoflora española. Butll. Soc. Catalana Micol, 14-15, 131-142.

Yoshimi, S. \& Doi, Y., 1989: Japanese gasteromycetes notes (1). Memoirs of the National Science Museum, 22, 29-41.

Zeller, S.M. \& Dodge, C.W., 1936: Melanogaster. Annals of the Missouri Botanical Garden, 23(4), $639-655$. 


\title{
SAŽETAK
}

\section{Novi podaci o podzemnim gljivama Turske}

\author{
O. Kaygusuz, Ö. F. Çolak, N. Matočec \& I. Kušan
}

Podzemne vrste gljiva klasificiraju se u tri odjeljka carstva gljiva: Ascomycota, Basidiomycota i Glomeromycota. Većina njih tvori ektomikoriznu vezu s korijenovim sustavom biljaka iz porodica Pinaceae, Fagaceae, Betulaceae, Myrtaceae i Salicaceae. Plodišta ovih gljiva razvijaju se djelomično ili u potpunosti pod zemljom te da bi se rasprostranile u zrelosti razvijaju mirise i tako privlače životinje koje se njima hrane. Spore se rasprostiru putem životinjskih ekskremenata. Zbog svoje ukusnosti i hranjivosti podzemne gljive dio su i ljudske prehrane od davnih vremena. Zbog svojeg položaja unutar tri fitogeografske regije, poluotok Anatolija odlikuje se velikom raznolikošću biljaka, što za posljedicu ima i visoku bioraznolikost podzemnih gljiva kojih je do danas u Turskoj zabilježeno 71 vrsta. Uzorci podzemnih gljiva prikazanih u ovome radu sakupljeni su na području turskih provincija Aydın, Bursa i Kütahya bez pomoći treninranih pasa u okviru planiranih istraživanja tri međusobno vrlo različitih tipova staništa: (a) termomediteranske primorske vegetacije u kojoj dominira brucijski bor (Pinus brutia) i obični čempres (Cupressus sempervirens) pokrajine Aydın, (b) montano-mediteranskoj vegetaciji libanonskog cedra (Cedrus libani), termofilnih listopadnih hrastova i bušina pokrajine Kütahya, te (c) Euro-sibirskoj altimontanoj šumi azijske bukve (Fagus orientalis) i kavkaske jele (Abies nordmanniana) pokrajine Bursa. Mirisna šupljoglavka (Hydnocystis piligera) je novozabilježena vrsta kao i rod (šupljoglavke) za mikobiotu Turske. Ekološki podaci kod ove vrste uspoređeni su s podacima iz Hrvatske (gdje je ona već 30 godina pod posebnim monitoringom) i ostalih država u kojima je zabilježena. Najveći broj nalaza pronađen je u sastojinama termofilnih vrsta mediteranskih borova. S proširenjem areala na područje Turske, glavni ekološki okvir ove vrste potpada pod termomediteranski bioklimatski pojas Sredozemlja s karakterističnom trajnozelenom tvrdolisnom vegetacijom i/ili termofilnom vegetacijom četinjača. Široko rasprostranjene transkontinentalne vrste Melanogaster variegatus i Octaviania asterosperma zabilježene su na novoistraženim lokalitetima u Turskoj. 
